\title{
Media Informasi Dan Promosi Berbasis Animasi Motion Graphic Pada PT. Elektrika Persada Solusindo
}

\author{
Dewi Immaniar Desrianti ${ }^{* 1}$, Arkan Nur Robby ${ }^{2}$, Rina Eva M. Simamora ${ }^{3}$ \\ ${ }^{1,2,3}$ Program Studi Teknik Informatika Fakultas Sains dan Teknologi Universitas Raharja \\ Jl. Jend. Sudirman No. 40, Modern Cikokol, Tangerang \\ E-Mail : $\underline{\text { *1 dewi.immaniar@ raharja.info }},{ }^{2}$ arkan@ raharja.info,${ }^{3}$ rina.eva@ raharja.info
}

\begin{abstract}
Abstrak
Pesaing dalam dunia bisnis di era saat ini terus berkembang dengan mengikuti tren di era digital yang membuat setiap perusahaan berlomba-lomba memasarkan produknya. Apalagi dalam situasi saat ini, penyebaran virus pandemi yang disebut COVID-19 belum berakhir, sehingga setiap perusahaan harus meningkatkan penyebaran informasi dan promosi pada khalayak dikarenakan penyebaran virus ini mengakibatkan banyak perusahaan yang kesulitan dalam menjangkau klien. PT. Elektrika Persada Solusindo merupakan salah satu dari banyaknya perusahaan yang terkena dampak akibat dari pandemi ini, terletak di Rukan Graha Mas - Kebon Jeruk Blok B No. 25 Jalan Raya Perjuangan, Jakarta Barat. Permasalahannya terdapat pada media dalam menginformasikan dan mempromosikan tentang PT. Elektrika Persada Solusindo, sebelumnya media yang digunakan hanya via webinar dan media cetak yang dirasa kurang signifikan di tengah pandemi saat ini. Tujuan penelitian ini adalah melakukan perancangan berupa profil video berbasis animasi motion graphic yang dapat dimanfaatkan dalam menginformasikan dan memprosomosikan tentang PT. Elektrika Persada Solusindo. Hasil dari penelitian ini berupa profil video berbasis animasi motion graphic. Metode penelitiannya berupa pengumpulan data dan konsep produksi media (KPM). Diharapkan dengan terwujudnya audio visual berbasis motion graphic ini, khalayak dan khususnya target audiens dapat lebih mengenal secara utuh dan komprehensif mengenai PT. Elektrika Persada Solusindo.
\end{abstract}

Kata kunci - Audio Visual, Informasi, Promosi, Motion Graphic

\begin{abstract}
Competitors in the business world in the current era continue to develop by following the trends in the digital era that make every company compete to market their products. Especially in the current situation, the spread of the pandemic virus called COVID-19 has not ended, so every company must increase the dissemination of information and promotion to the public because the spread of this virus has resulted in many companies having difficulty reaching clients. PT. Elektrika Persada Solusindo is one of the many companies affected by this pandemic, located at Rukan Graha Mas - Kebon Jeruk Blok B No. 25 Jalan Raya Perjuangan, West Jakarta. The problem lies with the media in information and promoting PT. Elektrika Persada Solusindo, previously the media used was only via webinar and print media which were deemed insignificant in the midst of the current pandemic. The purpose of this research is to design a video profile based on motion graphic animation that can be used to inform and promote about PT. Elektrika Persada Solusindo. The result of this research is a video profile based on motion graphic animation. The research method is in the form of data collection an the concept of media production (KPM). It is hoped that with the realization of this motion graphics-based audiovisual, the audience and especially the target audience can get to know more fully and comprehensively about PT. Elektrika Persada Solusindo.
\end{abstract}

Keywords - Audio-Visual, Information, Promotion, Motion Graphic 


\section{PENDAHULUAN}

Informasi adalah suatu pertambahan dalam ilmu pengetahuan yang menyumbangkan kepada konsep kerangka kerja yang umum dan fakta - fakta yang diketahui, Informasi bertumpu pada konteks dan pengetahuan umum si penerima untuk kepentingannya. ${ }^{[1]}$

Promosi merupakan suatu kegiatan yang bertujuan untuk memperkenalkan suatu produk berupa barang dan jasa kepada masyarakat luas, sehingga menarik minat untuk membeli atau menggunakan barang yang dipromosikan. Penyebarannya dengan memanfaatkan media, yaitu media televisi, media cetak, dan media lainnya.

Informasi memperlihatkan hasil pemrosesan data yang berguna bagi penerimanya. Informasi itu harus lengkap untuk memastikan bahwa aspek penting yang mengukur aktivitas tidak hilang.

Untuk menginformasikan dan mempromosikan, media dapat berupa media audio, media visual, dan media audio visual. Media audio, dimana media ini hanya menyampaikan informasi dengan cara memperdengarkan isi dari informasi tertentu. Media visual yaitu media yang menyampaikan informasi dengan cara memperlihatkan informasi tersebut dalam media cetak. Sedangkan media audio visual, memvisualisasikan sekaligus memperdengarkan isi pesan atau informasi tersebut.

Animasi adalah rangkaian gambar yang membentuk sebuah gerakan. Salah satu keunggulan animasi dibanding media lain seperti gambar statis atau teks adalah kemampuannya untuk menjelaskan perubahan keadaan tiap waktu. Hal ini terutama sangat membantu dalam menjelaskan prosedur dari urutan kejadian ${ }^{[2]}$

Motion Graphic merupakan salah satu cabang ilmu desain grafis, dimana dalam motion graphic terdapat elemen-elemen desain seperti bentuk, raut, ukuran, arah, tekstur di dalamnya, dengan secara sengaja digerakkan atau diberi pergerakan. Perbedaan motion graphic dengan desain grafis adalah pada media aplikasinya, apabila pada desain grafis elemen-elemennya statis (diam) dan terdapat pada media cetak, sementara elemen pada motion graphic memiliki gerakan sehingga terlihat dinamis dan ditampilkan melalui audio visual. ${ }^{[3]}$

PT. Elektrika Persada Solusindo adalah Perusahaan Distributor Produk terkemuka yang mana saat ini merupakan salah satu perusahaan yang terkena dampak akibat pandemi yang melanda seluruh dunia, sehingga mengalami kesulitan dalam menginformasikan dan mempromosikan. Sebelumnya perusahaan ini dalam menginformasikan dan mempromosikan hanya via webinar dan media cetak berupa brosur. Namun melihat begitu kondisi sekarang dan banyak pesaing di era perkembangan digital yang tidak ada habisnya, media yang digunakan pada PT. Elektrika Persada Solusindo dianggap kurang signifkan, maka penulis melakukan penelitian perancangan animasi motion graphic.

Dalam pembuatan Motion Graphic PT. Elektrika Persada Solusindo menggunakan beberapa software pendukung, yaitu : (1) Adobe Illustrator merupakan perangkat lunak desain grafis yang digunakan dalam pembuatan gambar dan ilustrasi vektor. Adobe Illustrator adalah produk pendamping dari Adobe Photoshop ${ }^{[4]}$. (2) Adobe After Effects adalah perangkat lunak untuk mengedit dan membuat efek khusus. Perangkat lunak ini hanya cocok untuk bagian tertentu, bukan untuk fungsi pengeditan video yang panjang. (3) Adobe Audition adalah multitrack digital audio recording, editor dan mixer yang udah digunakan dan memiliki berbagai fasilitas pengolahan suara. Dengan Adobe Audition dapat merekam suara, memperbaiki kualitas suara, menambahkan berbagai efek suara, dan menggabungkan dengan berbagai track suara menjadi satu track, dan menyimpan dalam berbagai format, Adobe Audition banyak digunakan oleh musician recording master, demo $c d$, produser dan programing stasiun radio. ${ }^{[5]}$

Penelitian yang diteliti oleh Maria, dkk (2019) ${ }^{[6]}$ berjudul "Visualizing The Terror Threat. The Impact Of Communicating Security Information To The General Public Using Infographics And Motion Graphics." Pada penelitian ini, penulis memvisualisasikan informasi yang kompleks dengan infographic dan motion graphics. Hasil penelitian ini memberikan 
pedoman penting tentang bagaimana mengkomunikasikan informasi keamanan tentang teror secara efektif ke publik, dengan implikasi praktis bagi keamanan.

Penelitian yang diteliti oleh Kukoh Mey, dkk (2020) ${ }^{[7]}$ brerjudul "Media Promosi Animasi Motion Graphic Pada PT. Tirta Karya Buana." Penulis menjelaskan dalam mendapatkan layanan berkualitas dan berdampak terhadap kepuasan pelanggan, perlunya pengembangan media audiovisual yang dapat memperkenalkan dan mempromosikan jasa kepada masyarakat dan hal tersebut berupa video animasi motion graphic.

Penelitian yang diteliti oleh Puad Abdul, dkk $(2020)^{[8]}$ berjudul "Media Informasi dan Promosi berbasis Motion Graphic pada PT. NL Indonesia". Penelitian ini menerangkan bahwa dengan perkembangan digital saat ini, media promosi dan informasi berupa slide presentasi dan media online berupa website dianggap kurang menarik, sehingga dibutuhkan media yang lebih mampu dan menarik simpati publik yaitu berupa video animasi berbasis motion graphic.

Penelitian yang diteliti oleh Mohd Hafiz, dkk (2020) ${ }^{[9]}$ berjudul "Design Process: $2 D$ Interactive Video Animation Development For Cosmetic Awareness Among Women" Penelitian ini menerangkan bahwa sebelum wanita mengaplikasikan kosmetik, ada baiknya untuk mengetahui tentang kulit sensitif mereka dan produk yang dipakai. Penelitian ini bertujuan untuk meningkatkan kesadaran wanita di Malaysia terhadap pengaruh penggunaan kosmetik dan kebersihan alat kosmetika, seperti sikat dan spons.

\section{METODE PENELITIAN}

Menggunakan beberapa metode penelitian untuk melengkapi dan memperoleh data terkait dengan perancangan animasi motion graphic, yaitu : (1) Pengumpulan data melalui (a) Observasi, memperoleh data yang diperlukan dengan pengamatan secara langsung dan melakukan catatan sistematis dari unsur yang diteliti. (b) Wawancara, mengintegrasikan data dengan mendatangi pihak stakeholder secara langsung dan melakukan tanya jawab, pihak stakeholder disini yaitu staff sales engineer.(c) Analisa Perancangan Media dengan mengunakan software penunjang video dan grafis, yaitu Adobe After Effects dan Adobe Illustrator. (4) Tahapan Konsep Produksi Media (KPM) merupakan tahapan berurut yang dilakukan guna untu mengatur proses produksi media agar memiliki konsep yang jelas sesuai dengan keinginan stakeholder.

\section{HASIL DAN PEMBAHASAN}

\subsection{Pre-Production}

Preproduction berhubungan dengan pencarian ide hingga menjadi konsep dalam bentuk naskah, rundown, pembentukan tim kerja, penentuan lokasi, penyusunan biaya, penentuan pengisi acara, menentukan/membangun set. ${ }^{[10]}$

1. Ide/ Gagasan

Media audiovisual yang sering dilihat adalah perwujudan suatu pandangan atau keinginan yang telah diinjeksikan kedalam sarana tersebut dan dalam hal ini berupa video berbasis animasi motion graphic. Konsep yang diinginkan mengambil informasi dengan menyesuaikan latar belakang perusahaan, yaitu PT. Elektrika Persada Solusindo. Desain ini nantinya akan ditampilkan dengan menggunakan teknik grafis gerak.

2. Sinopsis

Sinopsis merupakan gambaran atau ringkasan dari alur atau jalannya cerita. Sinopsis disusun untuk memudahkan dalam memahami alur yang akan dibuat dalam proses produksi nantinya. Berikut sinopsis dari motion graphic PT. Elektrika Persada Solusindo :

"PT. Elektrika Persada Solusindo didirikan pada tahun 2012 dengan Manajemen dan Tim Teknisi yang berpengalaman dan berkompetensi tinggi di bidang Elektrikal dan Mekanikal. Perusahaan yang sampai saat ini bekerja sama dengan produk-produk terkemuka seperti, 
Work Italia, TEMA - Italia, KuDos - Taiwan, Metrycom, dan NL Acoustics. PT. Elektrika Persada Solusindo memiliki relasi klien yang sangat luas mencakup Badan Usaha Milik Negara (BUMN) maupun perusahaan-perusahaan swasta dan telah menyelesaikan banyak proyek besar."

3. Narasi

Naskah merupakan Istilah umum yang merujuk pada naskah tertulis suatu pertunjukan, skenario, atau siaran, yang digunakan dalam produksi atau pertunjukan, lengkap berisi cerita, setting, dan dialog. Sebuah skrip bisa saja berupa screenplay, shooting script, lined script, continuity script, atau spec script. ${ }^{[11]}$ Berikut teks dubbing pada video profile berbasis animasi motion graphic ini :

"Perusahaan ini bergerak di bidang usaha Penyediaan Jasa Pelayanan Teknik // Pengadaan Barang di Bidang Elektrikal, Mekanikal, dan Peralatan Kontrol dengan area layanan di seluruh Indonesia // Alamat kantor PT. Elektrika Persada Solusindo berada di Rukan Graha Mas - Kebon Jeruk Blok B No. 25 Jalan Raya Perjuangan, Jakarta Barat // PT. Elektrika Persada Solusindo merupakan Agen Tunggal dan Distributor dengan produk-produk terkemuka // Kudos Tools, Produk alat tools yang digunakan untuk pemotongan kabel dan alat press menghubungkan kabel // Work Italia, produk yang digunakan sebagai peralatan Ground Transmisi // T.e.m.a, produk yang digunakan untuk menarik kabel jaringan transmisi // Metrycom, produk yang digunakan untuk mendeteksi adanya kotoran di Isolator // PT. Elektrika Persada Solusindo memiliki relasi klien yang sangat luas mencakup Badan Usaha Milik Negara (BUMN), Perusahaan Industri, dan kontraktor // Dan juga telah menyelesaikan beberapa Proyek di berbagai tempat.//"

4. Storyboard

Storyboard merupakan cetak biru, sketsa, atau gambar yang dilengkapi dengan petunjuk atau catatan pengambilan gambar untuk kebutuhan syuting, untuk menjelaskan adegan, dialog, dan eksyen, disertai catatan tentang proses pengambilan gambar, komponen audio, dan skrip. Penggambaran singkat jalan cerita secara visual ini juga disertai penjelasan alur cerita dan rencana-rencana pengambilan sudut gambar, pengisian suara, serta efek-efek khusus yang diperlukan. Storyboard cukup membantu dan mempermudah pembacaan isi cerita, karena menggambarkan isi cerita secara visual. Pembuat storyboard dikenal dengan istilah storyboard artist, yang membuat storyboard berdasarkan skenario sebagai panduan visual cerita. ${ }^{[13]}$

Dalam proses produksi, perencanaan terkait dengan visualisasi dibuat dengan bantuan storyboard sebagai media penunjang.

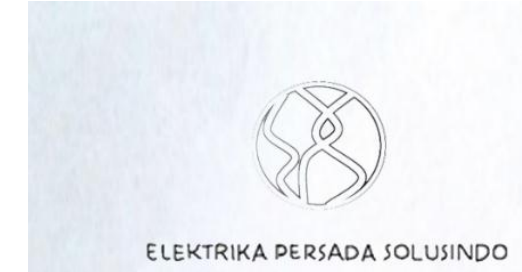

Gambar 1. Storyboard/ Scene 1/ Menampilkan Logo PT. Elektrika Persada Solusindo

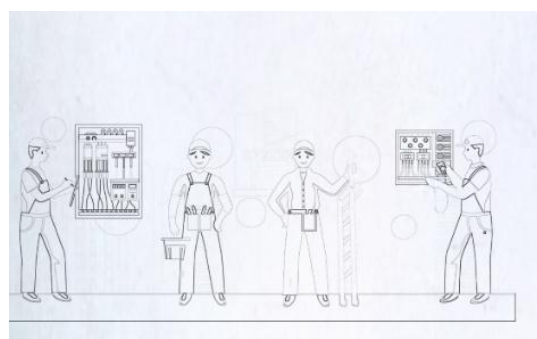

Gambar 2. Storyboard/ Scene 2/ Menampilkan Tim Teknik PT. Elektrika Persada Solusindo 


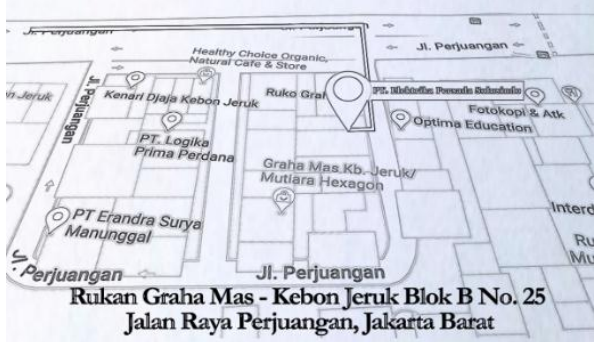

Gambar 3. Storyboard/ Scene 3/ Menampilkan Lokasi Perusahaan

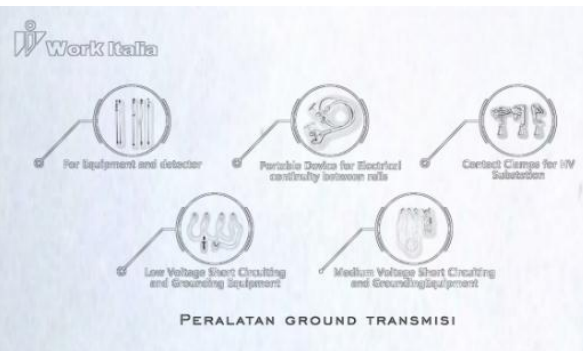

Gambar 5. Storyboard/ Scene 5/ Menampilkan Produk "Work Italia"

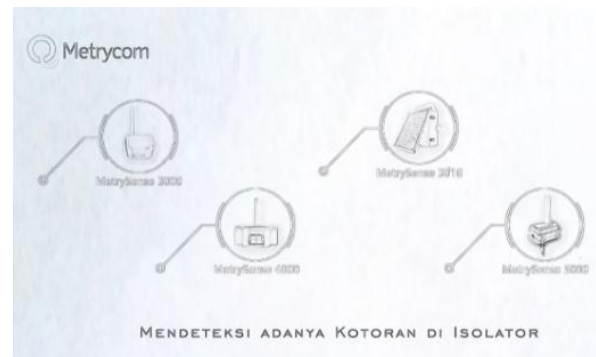

Gambar 7. Storyboard/ Scene 7/ Menampilkan Produk "Metrycom"

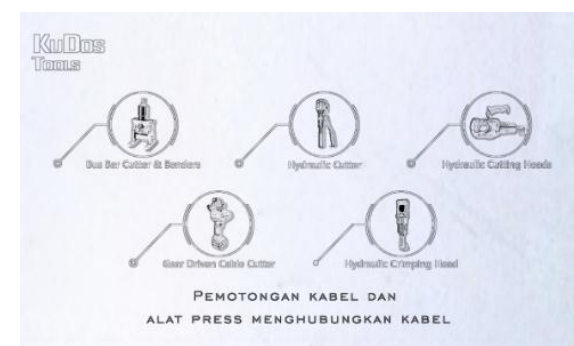

Gambar 4. Storyboard/ Scene 4/ Menampilkan Produk "Kudos Tools"

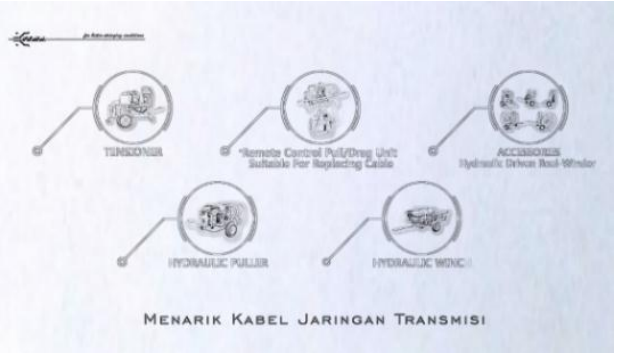

Gambar 6. Storyboard/ Scene 6/ Menampilkan Produk "Te.m.a"

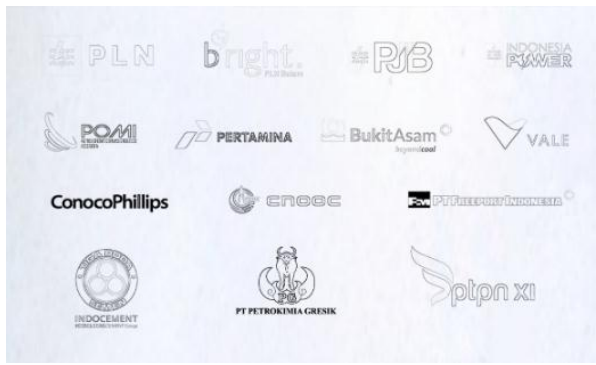

Gambar 8. Storyboard/ Scene 8/ Menampilkan Relasi Klien

5. Script Writing

Script Writing adalah sebuah taksiran dalam naskah yang diruaikan dari ide yang sebelumnya sudah dimuat dalam sinopsis untuk menentukan alur dalam sebuah cerita. Berikut tabel dari perancangan profil video pada PT. Elektrika Persada Solusindo.

Tabel 1. Script Writing

\begin{tabular}{|l|l|l|}
\hline No & \multicolumn{1}{|c|}{ Visual } & \multicolumn{1}{|c|}{ Audio } \\
\hline 1 & Menampilkan Animasi Logo PT. Elektrika Persada Solusindo & $\begin{array}{l}\text { Musik dan } \\
\text { Dubbing dan }\end{array}$ \\
\hline 2 & $\begin{array}{l}\text { Menampilkan Animasi Tim Teknisi PT. Elektrika Persada } \\
\text { Solusindo }\end{array}$ & $\begin{array}{l}\text { Musik dan } \\
\text { Dubbing dan }\end{array}$ \\
\hline 3 & Menampilkan Animasi Lokasi Perusahaan & $\begin{array}{l}\text { Musik dan } \\
\text { Dubbing }\end{array}$ \\
\hline 4 & Menampilkan Animasi Produk Kudos Tools dan penjelasannya & $\begin{array}{l}\text { Musik dan } \\
\text { Dubbing }\end{array}$ \\
\hline 5 & Menampilkan Animasi Produk Work Italia dan penjelasannya & $\begin{array}{l}\text { Musik dan } \\
\text { Dubbing }\end{array}$ \\
\hline
\end{tabular}


Print ISSN: 2723-1992

Online ISSN: 2723-200X

\begin{tabular}{|l|l|l|}
\hline 6 & Menampilkan Animasi Produk T.e.m.a dan penjelasannya & $\begin{array}{l}\text { Musik dan } \\
\text { Dubbing }\end{array}$ \\
\hline 7 & Menampilkan Animasi Produk Metrycom dan penjelasannya & $\begin{array}{l}\text { Musik dan } \\
\text { Dubbing }\end{array}$ \\
\hline 8 & Menampilkan Animasi Relasi Klien & $\begin{array}{l}\text { Musik dan } \\
\text { Dubbing }\end{array}$ \\
\hline
\end{tabular}

6. Rundown

Rundown merupakan suatu susunan cerita yang sudah didiskusikan sebelumnya dengan tim dan dibatasi oleh durasi (panjang proyek video).

Tabel 2. Rundown

\begin{tabular}{|c|c|c|c|c|c|}
\hline No & Scene & Location & Duration & INT/EXT & Description \\
\hline 1. & 1 & $\begin{array}{l}\text { Animasi Logo } \\
\text { Perusahaan }\end{array}$ & $\begin{array}{l}00: 00: 00 \quad- \\
00: 00: 04\end{array}$ & 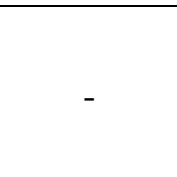 & \begin{tabular}{ll}
\multicolumn{3}{l}{ Menampilkan } \\
Animasi Logo PT. \\
Elektrika $\quad$ Persada \\
Solusindo &
\end{tabular} \\
\hline 2. & 2 & $\begin{array}{ll}\text { Animasi } & \text { Tim } \\
\text { Teknisi } & \\
\end{array}$ & $\begin{array}{l}00: 00: 04 \quad- \\
00: 00: 09\end{array}$ & - & $\begin{array}{l}\text { Menampilkan } \\
\text { Animasi Tim Teknisi }\end{array}$ \\
\hline 3. & 3 & $\begin{array}{l}\text { Animasi Lokasi } \\
\text { Perusahaan }\end{array}$ & $\begin{array}{l}\text { 00:00:09 } \\
00: 00: 18\end{array}$ & - & $\begin{array}{ll}\text { Menampilkan } & \\
\text { Animasi } & \text { Lokasi } \\
\text { Perusahaan } & \end{array}$ \\
\hline 4. & 4 & $\begin{array}{l}\text { Animasi Produk } \\
\text { "Kudos Tools" }\end{array}$ & $\begin{array}{l}00: 00: 18 \quad- \\
00: 00: 27\end{array}$ & - & \begin{tabular}{l}
\multicolumn{2}{l}{ Menampilkan } \\
Animasi Produk \\
Kudos Tools dan \\
Penjelasannya
\end{tabular} \\
\hline 5. & 5 & $\begin{array}{l}\text { Animasi Produk } \\
\text { "Work Italia" }\end{array}$ & $\begin{array}{l}00: 00: 27 \quad- \\
00: 00: 35\end{array}$ & - & $\begin{array}{l}\text { Menampilkan } \\
\text { Animasi Produk } \\
\text { Kudos Tools dan } \\
\text { Penjelasannya } \\
\end{array}$ \\
\hline 6. & 6 & $\begin{array}{l}\text { Animasi Produk } \\
\text { "Te.m.a" }\end{array}$ & $\begin{array}{l}00: 00: 35 \quad- \\
00: 00: 43\end{array}$ & - & $\begin{array}{lr}\text { Menampilkan } & \\
\text { Animasi } & \text { Produk } \\
\text { Te.m.a } & \text { dan } \\
\text { Penjelasannya } & \\
\end{array}$ \\
\hline 7. & 7 & $\begin{array}{l}\text { Animasi Produk } \\
\text { "Metrycom" }\end{array}$ & $\begin{array}{l}00: 00: 43 \quad- \\
00: 00: 51\end{array}$ & - & \begin{tabular}{lr}
\multicolumn{2}{|l}{ Menampilkan } \\
Animasi & Produk \\
Metrycom & dan \\
Penjelasannya & \\
\end{tabular} \\
\hline 8. & 8 & $\begin{array}{l}\text { Animasi Relasi } \\
\text { Klien }\end{array}$ & $\begin{array}{l}00: 00: 51 \\
00: 01: 00\end{array}$ & - & $\begin{array}{l}\text { Menampilkan } \\
\text { Animasi Relasi Klien } \\
\text { Perusahaan }\end{array}$ \\
\hline
\end{tabular}

7. Penyusunan Kru

Kru yang terlibat dalam pembuatan projek ini antara lain :

Tabel 3. Penyusunan Crew

\begin{tabular}{|l|l|l|}
\hline No & \multicolumn{1}{|c|}{ Jabatan } & \multicolumn{1}{c|}{ Nama } \\
\hline 1 & Director & Rina Eva Marolina Simamora \\
\hline 2 & Script Writer & Rina Eva Marolina Simamora \\
\hline 3 & Editor & Rina Eva Marolina Simamora \\
\hline 4 & Dubber & Ferinda Kusuma Ratih \\
\hline
\end{tabular}




\section{8. $\quad$ Time Schedule}

Tabel 4. Time Schedule

\begin{tabular}{|c|c|c|c|c|c|c|c|c|c|c|c|c|c|}
\hline & \multirow{2}{*}{ Tahapan } & \multicolumn{4}{|c|}{ Oktober 2020} & \multicolumn{4}{|c|}{ November 2020} & \multicolumn{4}{|c|}{ Desember 2020} \\
\hline & & 1 & 2 & 3 & 4 & 1 & 2 & 3 & 4 & 1 & 2 & 3 & 4 \\
\hline \multirow{10}{*}{ 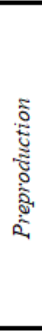 } & Observasi & & & & & & & & & & & & \\
\hline & Pengumpulan Data & & & & & & & & & & & & \\
\hline & Ide & & & & & & & & & & & & \\
\hline & Time Schedule & & & & & & & & & & & & \\
\hline & Proposal & & & & & & & & & & & & \\
\hline & Sinopsis & & & & & & & & & & & & \\
\hline & Script Writing & & & & & & & & & & & & \\
\hline & StoryBoard & & & & & & & & & & & & \\
\hline & Pemilihan Crew & & & & & & & & & & & & \\
\hline & Alat yang digunakan & & & & & & & & & & & & \\
\hline \multirow{4}{*}{ 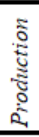 } & Perencanaan Multimedia & & & & & & & & & & & & \\
\hline & Perencanaan Audio & & & & & & & & & & & & \\
\hline & Perencanaan Visual & & & & & & & & & & & & \\
\hline & Perencanaan Broadcasting & & & & & & & & & & & & \\
\hline \multirow{6}{*}{ 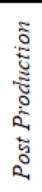 } & Digitizing & & & & & & & & & & & & \\
\hline & Editing & & & & & & & & & & & & \\
\hline & Mixing & & & & & & & & & & & & \\
\hline & Finishing & & & & & & & & & & & & \\
\hline & Exporting & & & & & & & & & & & & \\
\hline & Segmen Pasar & & & & & & & & & & & & \\
\hline
\end{tabular}

9. Peralatan yang digunakan

Dalam produksi motion graphic ini diproses dengan berbagai perangkat pendukung yang digunakan, diantaranya laptop, Clip On, Splitter, Headset, Flashdisk.

\subsection{Production}

Tahap selanjutnya dalam konsep produksi media adalah tahap produksi. Tahap ini dimana semua materi yang dibuat sebelumnya disatukan dalam pengawasan sutradara.

Dalam perancangan video profile PT. Elektrika Persada Solusindo, pemikiran ide yang telah dibuat dituangkan dalam bentuk storyboard yang kemudian dirancang dalam illustrasi digital dan kemudian dianimasikan dengan teknik motion graphic. Dalam tahap produksi, diperlukan beberapa tahapan proses perancangan multimedia, perancangan visual, dan perancangan broadcasting.

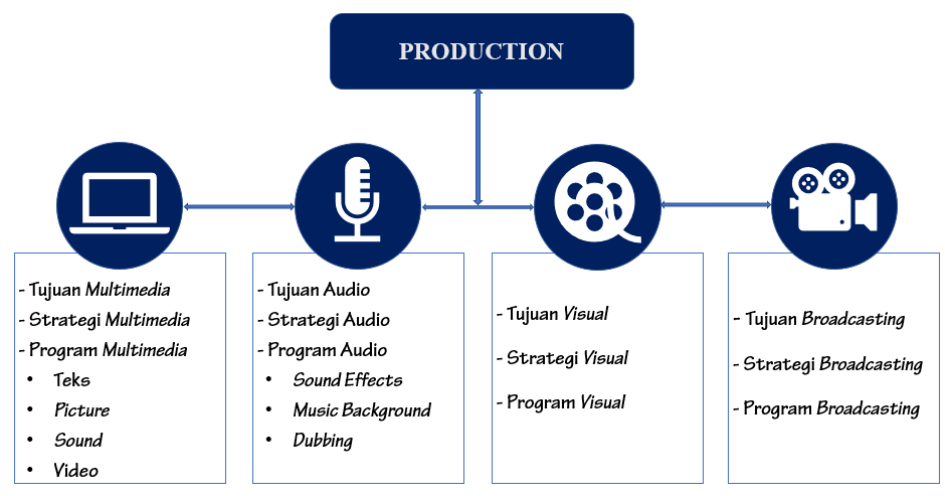

\section{Tampilan Visual}

Gambar 9. Production

Tampilan Visual dalam motion graphic ini mengenai penjelasan perusahaan yang melingkupi latar belakang perusahaan, lokasi perusahaan, produk-produk yang dijual, dan relasi klien perusahaan. Berikut hasil visual dari motion graphic PT. Elektrika Persada Solusindo: 


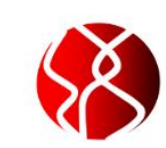

ELEKTRIKA PERSADA SOLUSINDO

Gambar 10. Visuall Scene 1/Menampilkan Animasi Logo PT. Elektrika Persada Solusindo

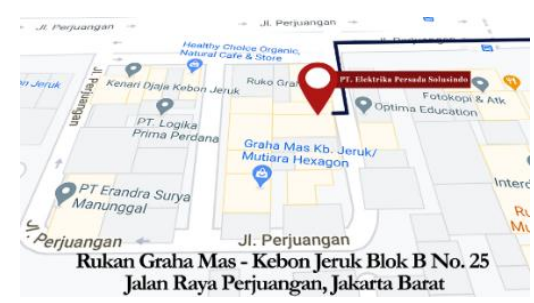

Gambar 12. Visuall Scene 3/ Menampilkan Animasi Lokasi Perusahaan

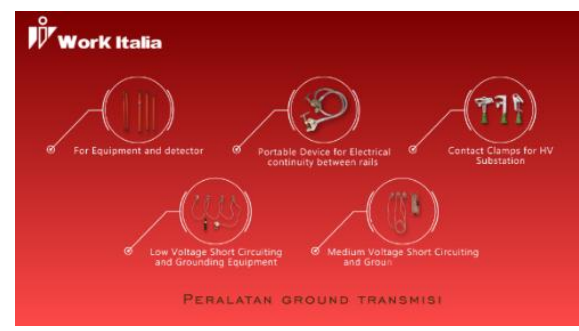

Gambar 14. Visual/ Scene 5/ Menampilkan Animasi Produk "Work Italia"

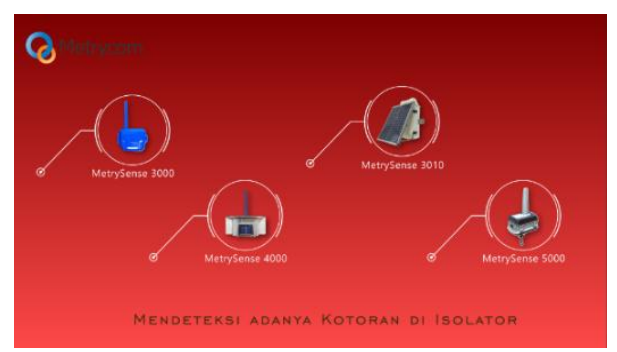

Gambar 16. Visual/ Scene 7/ Menampilkan Produk "Metrycom"

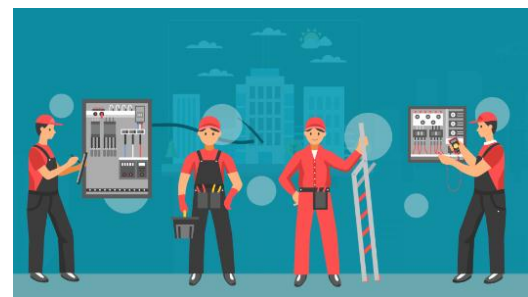

Gambar 11. Visual/ Scene 2/

Menampilkan Animasi Tim Teknik

PT. Elektrika Persada Solusindo

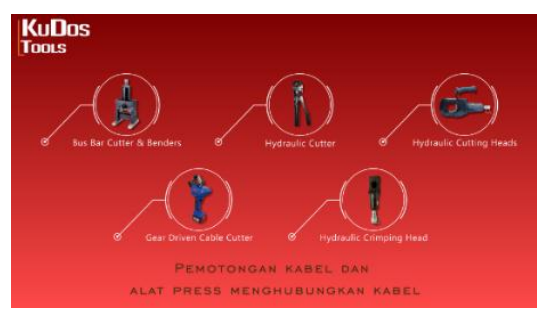

Gambar 13. Visual/Scene 4/ Menampilkan Animasi Produk "Kudos Tools"

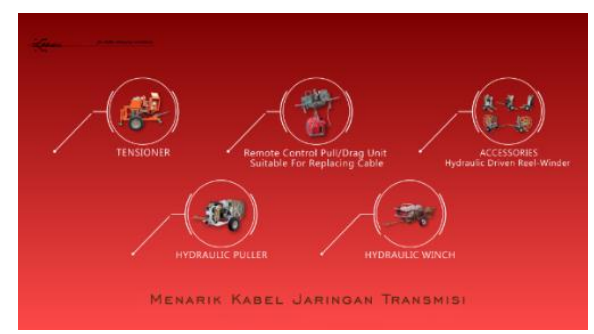

Gambar 15. Visual/ Scene 6/ Menampilkan Animasi Produk "Te.m.a"

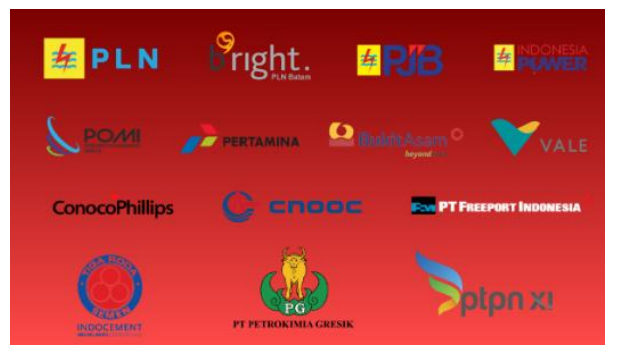

Gambar 17. Visual/ Scene 8/ Menampilkan Animasi Relasi Klien Perusahaan

\subsection{Post Production}

Tahapan ini merupakan tahapan akhir dari konsep produksi media. Pada tahapan ini proses pengeditan proyek dijalankan menjadi suatu karya video yang utuh. Pada tahap ini, melalui beberapa tahapan, diantaranya : Digitizing, Editing, Mixing, Exporting, dan terakhir Segmen Pasar. 
1. Digitizing (Digitalisasi)

Digitalisasi mengaju pada konversi data melalui gambar tercetak ke bentuk digital. Ilustrasi yang sudah dirancang di Adobe Illustrator dipindahkan ke Adobe After Effect, lalu konversikan menjadi video animasi berdasarkan grafik gerak selama proses pengeditan.

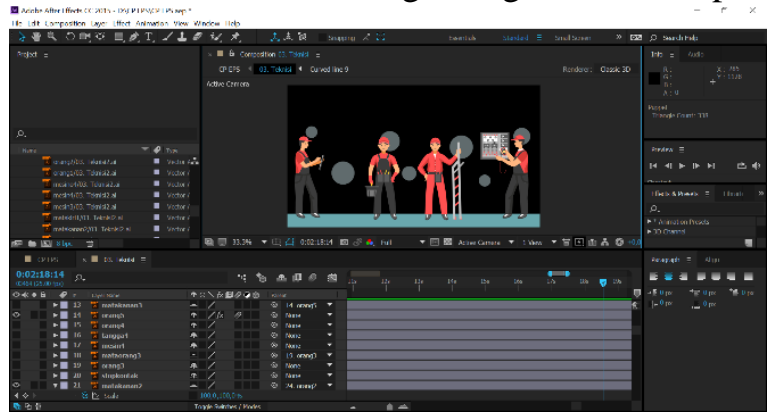

2. Editing

Gambar 18. Digitizing dari Adobe Illustrator ke Adobe After Effects

Tahapan ini dilakukan setelah tahapan sebelumnya. Pada tahap ini video yang sedang diproses akan dipotong, dipilih, dan disusun sesuai dengan yang diinginkan pada konsep yang sudah disesuaikan.

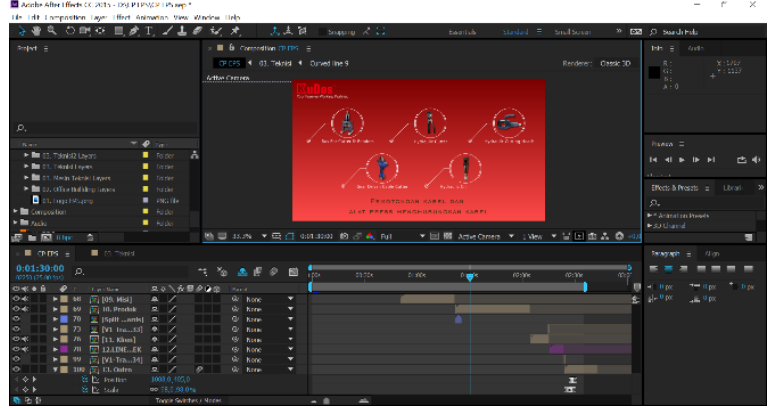

3. Mixing

Gambar 19. Editing menggunakan Adobe After Effects

Tahapan ini merupakan proses menyatukan beberapa materi seperti gambar yang diilustrasikan, efek spesial, backsound, dan dubbing serta menambahkan sedikit teks berdasarkan skrip atau storyboard yang diproduksi sebelumnya.

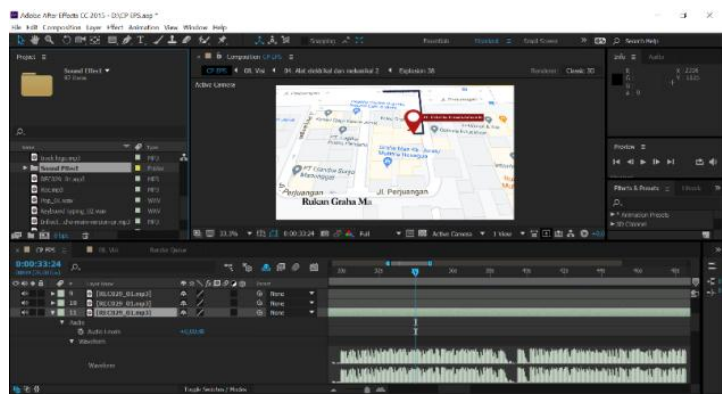

Gambar 20. Mixing

\section{Finishing}

Pada tahapan ini, editor melakukan pengecekan ulang apakah kombinadi dari gambar, teks, suara musik, maupun suara dari dubber yang disatukan pada perancangan ini sudah tersusun rapi secara keseluruhan. 


\section{Exporting}

Tahap ini merupakan tahapan akhir dari perancangan profil video ini, yang kemudian akan dirender dalam format yang sudah ditentukan. Kemudian hasilnya akan dipergunakan sebagai media dalam menginformasikan dan mempromosikan dan penyebarannya akan memanfaatkan sosial media.

6. Segmen Pasar

Pada tahapan ini, dimana video utuh yang sebelumnya telah dihasilkan hendaknya menetapkan pasar sasaran yang akan dituju untuk memperluas jangkauan khalayak dan hal ini berupa Perusahaan Industri, Badan Usaha Milik Negara (BUMN), dan Kontraktor. Diharapkan video profile ini dapat memberikan persentase target pasar pada PT. Elektrika Persada Solusindo sesuai dengan apa yang sudah ditetapkan.

\section{KESIMPULAN}

Penelitian yang dilakukan pada PT. Elektrika Persada Solusindo mengenai perancangan media informasi dan promosi, maka penulis mengambil kesimpulan dalam kendala yang dimiliki PT. Elektrika Persada Solusindo adalah kurangnya media yang mendukung informasi dan promosi secara online.

Untuk mendukung mengenai hal tersebut, maka diperlukan media yang tepat dalam menginformasikan dan mempromosikan PT. Elektrika Persada Solusindo yaitu media audio visual berupa animasi motion graphic. Motion Graphic berfokus pada ilustrasi, teks, audio dubber, dan audio effect yang dapat memberikan informasi dan efek visual yang jelas, membuat video terlihat lebih menarik dan hidup. Audio visual berupa motion graphic ini membentuk strategi pemasaran online dengan memanfaatkan platform sosial media berupa Youtube, sehingga mampu menarik pangsa pasar yang lebih luas.

\section{SARAN}

Berdasarkan hasil penelitian yang disimpulkan, penulis menyarankan PT. Elektrika Persada Solusindo untuk selalu mengupdate audio visual berbasis motion graphic ini lebih baik lagi seiring berkembangnya kemajuan teknologi dan up to date menginformasikan tentang produk dan kualitasnya yang dapat meningkat dari waktu ke waktu. Disarankan juga untuk lebih memperluas cakupan informasi dan kegiatan promosi di seluruh Indonesia melalui penggunaan sosial media.

\section{DAFTAR PUSTAKA}

[1] Tyoso, Jaluanto Sunu Punjul. 2016. Sistem Informasi Manajemen.Yogyakarta:Deepublish

[2] Simarmata, J., Sibarani, C. G. G. T., \& Silalahi, T. (2019). Pengembangan Media Animasi Berbasis Hybrid Learning. Yayasan Kita Menulis.

[3] Saputra, A. B. (2018). Pembuatan Motion Graphic Sebagai Media Promosi Untuk Proyek DATSUN SIGAP. KOPERTIP: Jurnal Ilmiah Manajemen Informatika dan Komputer, 2(2), 84-97.

[4] Enterprise, J. (2018). Otodidak Adobe Illustrator. Elex Media Computindo: Jakarta. 
[5] Asrie, T. W. Pembuatan Video Klip Animasi 2d Band Vignecvara sebagai Media Promosi Band Indie YOGYAKARTA (Studi Kasus: Band Vignecvara) (Doctoral dissertation, University of AMIKOM Yogyakarta).

[6] Lonsdale, M. D. S., David, L., Baxter, M., Graham, R., Kanafani, A., Li, A., \& Peng, C. (2019). Visualizing the terror threat. The impact of communicating security information to the general public using infographics and motion graphics. Visible Language, 53 (2). pp. 37-71. ISSN 0022-2224

[7] Ariyanto, K., Zainudin M. N, A., \& Aulia Fajar, A. (2020). Media Promosi Animasi Motion Graphic pada PT. Tirta Karya Buana. MAVIB Journal, 1(2), 155-164.

[8] Abdul Baqi, M. P., Budiarto, M., \& Sumiati, D. (2020). Media Informasi dan Promosi Berbasis Motion Graphic Pada PT. NL Indonesia. MAVIB Journal, 1(2), 217227.

[9] Kamil, M. H. F. M., Abidin, I. S. Z., \& Osman, F. F. (2020). Design Process: 2D Interactive Video Animation Development For Cosmetic Awareness Among Women. Journal of Critical Reviews, 7(8), 891-894.

[10] Latief, R. (2020). Panduan Produksi Acara Televisi Nondrama. Prenada Media.

[11] Zoebazary, M. I.(2016). Kamus Televisi \& Film.Jember:Paguyupan Pandhalungan Jember. 